\title{
FOUCAULT E A LITERATURA (ARQUEOLOGIA DA LOUCURA E ESCRITA LITERÁRIA)
}

\author{
Augusto Bach \\ UNICENTRO-PR
}

\begin{abstract}
This article intends to show how Michel Foucault is reading the western civilization history of knowledge in his major work Madness and Civilization. During the sixty years, Foucault has always been worried about the meaning through we use to understand ourselves. Researching the rational language, he discovers an astonished way of discourse that hide us ours most basic decisions. He calls it literature. Digging until the most depth and unknown level of our culture, Foucault's archeology shares since the forward of Madness and Civilization some philosophical notions that, first of all, shall be clarified before any interpretation of his work.
\end{abstract}

Keywords: philosophy, Foucault, literature, archaeology.

Resumo: Este artigo procura mostrar como Michel Foucault opera a leitura dos saberes da civilização ocidental em sua grande obra A História da Loucura. Ao longo dos anos sessenta, Foucault sempre esteve preocupado acerca da maneira com que usualmente nos concebemos. Investigando a linguagem racional ele descobre uma surpreendente modulação discursiva que esconde nossas mais básicas escolhas. Ele a chama de literatura. Cavando até o mais profundo e desconhecido nível de nossa cultura, a arqueologia de Foucault compartilha desde o prefácio de História da Loucura algumas noções filosóficas que, acima de tudo, demandam um esclarecimento prévio antes de qualquer interpretação de seu pensamento.

Palavras-chave: filosofia, Foucault, literatura, arqueologia. 
"Como meus trabalhos concernem essencialmente à história, quando trato do século $X I X$ ou do século $X X$, prefiro apoiar-me nas análises de obras literárias, mais do que me apoiar nas obras filosóficas. Por exemplo, as escolhas operadas por Sade são muito mais importantes para nós do que o foram para o século XIX. E é por estarmos ainda sujeitados a tais escolhas que somos conduzidos a escolhas inteiramente decisivas. Eis por que eu me interesso por literatura, uma vez que ela é o lugar onde nossa cultura operou algumas escolhas fundamentais. (Foucault in Loucura, Literatura e Sociedade).

\section{Introdução}

É bastante comum encontrarmos na literatura de comentários sobre a obra de Michel Foucault estudos acerca de sua inédita concepção de subjetividade e de sua belicosa relação com a modernidade. Sabe-se, por exemplo, que a enquete empreendida desde seu primeiro livro, História da Loucura, invertera ao sujeito ocidental a imagem de seu duplo especular, a loucura, convertendo-se assim no signo da ruptura com uma história que se apoiava em um processo racional, contínuo e evolutivo. Daí então o crédito de ineditismo atribuído às suas análises. Com efeito, tal perspectiva evolucionista sempre se propôs a encontrar um sentido entre as diferentes etapas da cultura ocidental ao longo da épocas; aceitando como premissa que as formas de concepção mais simples do mundo e do real evoluem naturalmente para as mais complexas e atuais, procurando estabelecer assim as leis históricas que presidiriam o progresso de nossa civilização. De acordo com esse horizonte, para atribuir um nexo à história é mister descobrir a direção em que se movem seus artífices; e para compreender qual é essa direção seria preciso retornar a percorrer os vários estágios do movimento histórico e desvelar as razões da passagem de uma para outra etapa, assim como o telos desse movimento geral.

Ora, demonstrar o infundado desse gênero de pesquisa foi sempre uma característica da filosofia foucaultiana. Com esse propósito de fato, necessário se faz ao arqueólogo abandonar a velha concepção etnocêntrica de civilização como um estado de coisas ideal de que gozaria o Ocidente em seu estágio moderno e ao qual deveriam atingir todos os demais estágios primitivos de nossa cultura, sob a tutela das noções e conceitos mais avançados ou científicos. Seria mais transparente e neutro imaginarmos então 
uma seqüência aberta e infinita de transformações, pois sem começo nem fim, no desenrolar dos acontecimentos abrindo mão das ilusões míticas da origem primeira e de toda e qualquer interpretação triunfalista da história. Não mais um pensamento da história subordinado à lei do Um, muito menos a promessa de submissão a uma melhor dominação na serena crônica horizontal dos grandes acontecimentos, mas uma história que não coincide com a consciência que os homens dela tiveram; sempre diferente do que habitualmente se crê e irredutível a uma síntese subjetiva. Destarte, para Foucault a compreensão do estado atual da loucura para nossa época decorreria de uma análise que se ativesse antes aos fenômenos da loucura tal como sua época realmente a produziu, num intercâmbio de experiências e ensinamentos mútuos. Outrora fazia-se a história sem preocupações dessa ordem, permanecendo no relato cronológico dos fatos. Quando muito, partia-se de interpretações fantasistas suscetíveis das mais absurdas convicções impensadas: por exemplo, a idéia mítica de um bom selvagem tão cara a Rousseau. Pois justamente a idéia de mito sugere um ponto de origem, um centro a partir do qual se irradiaria a extensão de toda a grande continuidade da história. Já Foucault, por sua conta e risco, deseja encarar a história sob outro prisma, enxergando cortes, descontinuidades entre as etapas descritas e imprimindo nela a fecundidade de seu novo pensamento.

Ipso facto, aquele que opera uma leitura dos acontecimentos sem critérios de apoio à sua linguagem tem poucos elementos para fixar a origem e o término dos universos simbólicos. Esta orientação anti-totalizadora e asistemática das análises de Foucault, sua preferência por níveis de historicidade alheios ao cômputo continuista, evolutivo e atenuador do conflito, desmancha a associação romântica entre o heroísmo do sujeito e a realização de sua obra, signo do progresso de nossa civilização. Associação entre autor e obra, aliás, cujo potencial de redenção harmonizadora de nossa humanidade anima os esquemas intelectuais da fenomenologia. Há sempre uma nostalgia do Uno e da identidade por trás de nossas filosofias historicamente constituídas, uma vontade de verdade que se esconde atrás de seus humanismos e racionalismos dialéticos, da obsessão em reconduzir a origem e a gênese às formas transcendentais do sujeito. Já para um antifilósofo obstinado tal como se pretendia Foucault, a filosofia seria apenas um justificativa da ordem estabelecida que legitima o conhecimento empírico através de suas determinações transcendentais. 


\section{A relação arqueológica entre loucura e escrita literária}

Com efeito, se desde o início de sua carreira Foucault não pôde legitimamente em sua escrita - pois esta é uma questão de legitimidade e não de legalidade empírica - partir de verdades terminais que sustentassem o devir de suas análises, é precisamente porque não apoiou o seu projeto na figura da Coruja de Minerva tal qual a moderna filosofia da história hegeliana ${ }^{1}$; e sim em outras figuras tais como Hölderlin, Artaud, Nerval, Nietzsche, Van Gogh capazes, segundo ele, de realizar a mediação entre as separadas palavras da razão e da loucura e enunciar assim a mais que primitiva e trágica voz subterrânea da loucura.

Foucault enaltece no corpus literário composto pelas obras artísticas destes autores seu parentesco com o murmúrio surdo da linguagem da loucura, que os saberes racionais em seu devir horizontal desclassificaram. Consoante suas análises, o papel executado por estes artistas fora o de emprestar seus ouvidos a uma experiência nua da desrazão que, sendo prioritária em relação ao discurso científico, seria a mais radical descoberta da loucura. Como singulares pensadores que souberam entrever o "soberano trabalho da desrazão", estariam eles então retomando em nossos tempos uma positividade artística que abre, senão uma lacuna, todo um novo espaço de contestação do conhecimento racional ao prepararem, para além da cultura, uma relação com aquilo que nossa própria cultura rejeita. Eles falam dos confins fora da escrita primando por uma linguagem não-dialética, em direção a uma exterioridade nua e destituidora da fonte subjetiva de enunciações bem como da verdade do enunciado. $\mathrm{Na}$ emergência de um discurso anônimo sem pátria nem data, os literatos teriam exprimido para Foucault o esboço de uma escolha original que emerge em nossa cultura assinalando os limites de sua ordenação. Operando sobre uma outra disposição da linguagem, ao mesmo tempo de nossa mais antiga memória e promessa de um novo recomeço, eles desfazem a legitimidade em que se assenta a ratio ocidental. Parafraseando Foucault, eis aí toda a nossa

\footnotetext{
1 "Quando a filosofia chega com sua luz crepuscular a um mundo já a anoitecer, é quando uma manifestação da vida está prestes a findar. Não vem a filosofia para a rejuvenescer, mas apenas reconhecê-la. Quando as sombras da noite começaram a cair é que levanta 0 vôo 0 pássaro de Minerva." (HEGEL; Princípios da Filosofia do Direito p.17).
} 
circunstancial identidade histórica sendo contestada verticalmente por uma abafada diferença que não deixou de permanecer em vigília.

"A crítica de Nietzsche, todos os grandes valores investidos na partilha dos asilos e a grande procura que Artaud, após Nerval, efetuou implacavelmente em si mesmo, são suficientes testemunhos de que todas as outras formas de consciência de loucura ainda vivem no âmago de nossa cultura. O fato de só poderem receber uma formulação lírica não prova que estão perecendo, nem que prolongam, apesar de tudo, uma existência que o saber recusou há muito tempo, mas que, mantidas (todas essas formas de consciência) nas trevas, elas vicejam nas formas livres e mais originárias da linguagem. E o poder de contestação que têm é sem dúvida ainda mais vigoroso." (FOUCAULT, (3) 1978, p. 171-172).

Vê-se pelo exposto acima que Foucault está perseguindo desde História da Loucura uma maneira original para se aproximar de uma outra consciência da loucura. Pois o papel repressivo que a linguagem de razão executa em nossa cultura parece resultar justamente de sua condição cativa no mundo da representação. Ao invés de assegurar a serena e apolínea concepção de uma continuidade evolutiva de nossa razão - apoiada portanto na figura da Coruja de Minerva - ele insere antes a noção dionisíaca de uma crise em nosso mundo moderno amparada nas obras artísticas de poetas que colocam, por sua vez, toda a nossa estrutura representativa de pensamento em questão. Pois quanto maior e mais forte for o processo de ocultação histórico que mantém na sombra essas formas murmuradas de linguagem, com maior força transgressiva de contestação elas retornarão. Numa palavra: o recalque e o retorno deste recalcado obedecem a uma única e mesma estrutura herdada historicamente posta pela arqueologia em questão. Diante da degradação contínua da história, vê-se o passado arcaico com certa benevolência e o futuro com pesar; têm-se uma concepção pessimista da história encarada não mais como progresso indefinido, mas como um movimento cuja solução estaria num regresso definido a um espaço situado fora dela, como que sobrevivente ainda em seu âmago.

No entanto, para explorar esta região inédita, seria preciso renunciar a toda e qualquer atitude, técnica e aos conceitos herdados previamente desta separação histórica, como o de recalque por exemplo. Pois são estas formas 
de consciência crítica ocultadas pelo mundo moderno, grande e enigmático tesouro de legitimidade da pena foucaultiana, que funcionarão para a crítica arqueológica como o contraponto da história das condições de possibilidade dos saberes racionais legalmente formulados sobre a loucura. A experiência da linguagem literária no limiar do mapa de nossa cultura seria o ponto cardeal diferenciado, atribuído pela arqueologia de uma profunda reviravolta valorativa operada pelo Modernismo. Os testemunhos que nos fornecem cada um desses poetas conformam uma atividade de contra-efetuação, ao mesmo tempo ontológica e política, do mundo da representação e das ilusões transcendentais que aí se produzem. Na tentativa de articular uma outra significação que jaz no solo descontínuo de nossa cultura, Foucault associa seu empreendimento ao "fulgor" literário desses poetas.

É neste instante que podemos então entrever um romantismo inicial no pensamento de Michel Foucault, no começo dos anos 60, que procura nos libertar de nossas formas acolhedoras e habituais de pensamento. Até mesmo um anti-Sartre se encontra desta maneira obrigado a responder à questão " $O$ que é a literatura?”. Acreditando que a palavra literária poderia responder a inúmeras de suas interrogações, que se prolongarão no decorrer de seus escritos, o arqueólogo detecta nestas obras da literatura moderna uma alternativa romântica para nossa cultura tão obsedada de um humanismo fundamental, tão impregnada pela necessidade de justificação de seus atos mediante critérios racionais e harmonizadores. Foi percorrendo seus textos ao longo dos anos 60 que Foucault tentou encontrar outras maneiras de questionar determinadas noções filosóficas e de pensar a cultura ocidental por vieses diferentes. Se o modernismo literário é considerado por ele como um ponto de referência, é justamente porque este movimento cultural trouxe consigo uma forma de consciência da loucura que se encontrava de maneira esparsa, senão oculta, na sociedade. Analogamente, do mesmo modo que para um Sartre a literatura fornecia ao leitor uma consciência infeliz - fato que lhe possibilita tomar consciência da realidade que o permeia - o modo de ser da linguagem enunciada pela garganta desses poetas delirantes entrega à arqueologia a constatação da miséria dos projetos da época humanista.

Esta literatura modernista perfaz um caminho diferente não tanto pelo conteúdo político de sua mensagem, mas pelo fato de trazer à baila uma outra reflexão possível sobre o estatuto do Logos ocidental, nem sempre divorciado de seu contrário: a physis. A invenção artística da palavra literária, conforme o diagnóstico arqueológico, desfaz a positividade do mundo 
representativo da linguagem, desvelando as descontinuidades históricas que separam o ser da linguagem da loucura da língua de razão dissolvendo a aparência de uma verdade por simples correspondência, a ilusão de uma totalização do Ser pela linguagem. Maurice Blanchot, um dos expoentes desse movimento, introduzia nesta mesma época o conceito de Fora (dehors) como uma estratégia de pensamento para marcar justamente a falência do logos clássico e colocar em xeque noções fundamentais para a filosofia tais como a de autor e de representação.

Não obstante, ainda que Foucault tenha encontrado, numa espécie de emulação do caráter flexível e errante da linguagem presente na obra de um Blanchot, a inspiração para o seu pensamento, nem por isso a noção de Fora seguirá o mesmo rumo em sua arqueologia. É certo que a perspectiva histórica culturalista da arqueologia toma a forma de uma investigação da cultura ocidental descobrindo descontinuidades entre as dimensões epocais; que em suas pesquisas ele teve a coragem de contra-fazer as estruturas de evidência herdadas historicamente e a aparência de verdade sobre a qual escondem-se os discursos científicos. Mas se Foucault já começara seus estudos censurando o discurso psicopatológico por constituir-se como um monólogo da razão sobre a loucura, há nisto mais do que a crítica de um saber que está apoiado na negação da dimensão trágica da existência humana. Trata-se sobretudo de um retorno necessário ao conteúdo originário do saber filosófico mais autêntico e "representativo" do que a própria estrutura representativa do logos ocidental. ${ }^{2}$ Presente desde o início de suas linhas

\footnotetext{
2 É o que se pode observar de modo mais explícito, por exemplo, num artigo escrito para a revista Tel Quel em 1963. Curiosamente, aliás, com palavras que não deixam também de fazer ecos ao programa heideggeriano em Ser e Tempo. "Escrever, para a cultura ocidental, seria entrar no jogo de se colocar no espaço virtual da auto-representação e de redobramento; a escritura significando não a coisa, mas a palavra, a obra de linguagem não faria nada de outro senão avançar mais profundamente neste impalpável esgotamento do espelho, suscitar o duplo desse duplo que já é a escritura, descobrir assim um infinito possível e impossível, perseguir sem termo a palavra, a manutenção além da morte que a condena, e liberar o escorrimento de um murmúrio. Esta presença da palavra repetida na escritura dá sem dúvida ao que nós chamamos uma obra o estatuto ontológico desconhecido a essas culturas, onde, quando se escreve, é a coisa mesma que se designa. [...] Eu me pergunto se não se poderia fazer, ou ao menos esboçar à distância, uma ontologia da literatura a partir desses fenômenos de autorepresentação da linguagem. [...] Seria preciso começar por uma analítica geral de todas as formas de reduplicação da linguagem onde se podem encontrar exemplos na literatura ocidental. [...] A reduplicação da linguagem, mesmo se ela é secreta, é constitutiva de seu ser enquanto obra, e os signos em que se evidencia, é preciso lê-los como suas indicações ontológicas." (FOUCAULT; Le langage à l'infini in Dits et écrits / p.280-281).
} 
como aquilo que justifica a orientação da enquete, e no final como o que poderia responder ao apelo destes poetas, esta questão carrega a marca de uma nostalgia, da pretensão de deter o movimento histórico e de sua recusa. Não é seguro portanto afirmarmos que a letra de A História da Loucura jamais estivesse contaminada pelo peso das origens primeiras. Recordemos o aviso prévio já dado por Foucault em seu primeiro prefácio à História da Loucura quando nos lembrava que o logos grego não tinha contrário.

\begin{abstract}
"Os gregos relacionavam-se com alguma coisa que chamavam de hybris. Essa relação não era apenas de condenação; a existência de Trasímaco, ou a de Cálicles, basta para mostrálo, ainda que seu discurso nos seja transmitido, já envolto na dialética tranquilizadora de Sócrates. Mas o Logos grego não tinha contrário. O homem europeu, desde o recôndito da Idade Média, relacionava-se com alguma coisa que ele chama confusamente de: Loucura, Demência, Desrazão. É talvez a essa presença obscura que a Razão ocidental deve alguma coisa de sua profundidade, assim como à ameaça do hybris, a sofrosin dos discursos socráticos. Em todo caso, a relação Razão-Desrazão constitui para a cultura ocidental uma das dimensões de sua originalidade; ela já a acompanhava muito antes de Jheronimus-Bosch e a seguirá bem depois de Nietzsche e Artaud." (FOUCAULT, (4) 2002, p.188).
\end{abstract}

Ora, se historicamente o logos grego já nos é transmitido apenas por intermédio da "dialética tranquilizadora de Sócrates", como poderia então esta mesma dialética ser tranquilizadora se ela também participava do espaço de um saber em que o logos ainda não tinha contrário? Antes de mais nada, para resolver este aparente paradoxo, é preciso recordar que se a ética grega clássica se dava como um ideal da bela medida, harmonia, ordem e proporção é precisamente por que se tratava de opor à serenidade de um saber meticuloso (sofrosin) um real tumultuoso que o pensamento grego designava como hybris, como violência e extremidade. Neste âmbito, questionava-se se o Uno fundava o múltiplo ou se era o múltiplo que produzia o Uno como aparência. Assim, a desmesura (hybris), que era preciso mascarar para se produzir o ideal apolíneo da bela aparência, aparecia também como uma emoção que abolia toda e qualquer subjetividade; uma vez que ela se desvelava como a verdade dentro de um contexto em que a 
oposição entre as duas dimensões de saber (apolíneas e dionisíacas) era total (e não ainda tranqüilizadora). E se ao mesmo tempo para Foucault os gregos logravam domesticar e encobrir, graças a uma concepção apolínea da vida, um real desmedido que ameaçava destruí-los, é porque toda beleza era mera aparência que não deixava de supor uma verdade como sua essência. Hipótese metafísica que trabalha com as noções de essência e aparência pressupondo sempre a existência subjacente de um "uno originário", ser verdadeiro que não podia deixar de ser ignorado. A verdade, neste contexto, surgia não como a representação mais exata da realidade, mas como o efeito de um embate do logos grego com algo que lhe era exterior; era menos da ordem da descoberta intelectual do que da ordem da convicção.

Ao seu turno, a intermitente referência arqueológica aos literatos obedece sobremaneira a uma exigência de criação do novo a que atende o leitmotiv de suas análises, da criação do diferente em nossa cultura e que possibilite, por sua vez, a Foucault escapar de uma filosofia do sujeito, da consciência ou da representação portadoras de um sentido único e perene. $\mathrm{O}$ relacionamento do logos grego com algo de exterior - mas que não fora historicamente estabelecido ainda como seu contrário - executa no pensamento de Foucault o papel de uma matriz originária pela qual se avalia negativamente a modernidade. Já que a doutrina grega da ética não pressupunha a presença de um sujeito idêntico a si, mas antes a multiplicidade de um jogo de forças (entre as pulsões apolíneas e dionisíacas) que era preciso ordenar em vista de produzir-se a forma mais bela. Mutatis mutandis, no movimento mesmo da palavra literária e no modo subversivo de sua articulação manifestado em nosso século, a literatura constitui um espaço de transgressão em que tudo o que é fixo torna-se móvel abalando nossas estruturas de pensamento herdadas historicamente. Foucault não está dizendo, pois, que os literatos sejam os nossos verdadeiros filósofos, mas sim que eles sejam as mais vigorosas testemunhas do colapso de nosso saber filosófico. Eles falam não a partir do conhecimento filosófico, mas de uma linguagem trágica que nos é velada. Em outras palavras, ele constata em suas obras a linguagem entrando no domínio de um mesmo anonimato tão desejado para sua escritura; no âmbito de uma outra ética para o logos ocidental que não se organiza mais em torno da questão da verdade representativa. 
Ora, mas onde situarmos desde então, nessa estranha palavra vacante ou suspendida, o endereçamento ao outro sem o qual todo discurso não se transmite ou não retorna?

"O problema é saber em que direção vão os fios que tecem a escrita. Sobre esse ponto, a escrita posterior ao século XIX existe manifestamente para ela mesma e, se necessário, ela existiria independentemente de todo consumo, de todo leitor, de todo prazer e de toda utilidade. Ora, essa atividade vertical e quase intransmissível da escrita assemelha-se, em parte, à loucura. A loucura é, de algum modo, uma linguagem que se mantém na vertical, e que não é mais a palavra transmissível, tendo perdido todo o valor de moeda de troca: seja porque a fala perdeu todo o valor e não é desejada por ninguém, seja porque se hesita em servir-se dela como de uma moeda, como se um valor excessivo the tivesse sido atribuído. [...] Essa escrita não circulatória, essa escrita que se mantém de pé é justamente um equivalente da loucura. [...] Por trás de todo escritor esconde-se a sombra do louco que o sustenta, o domina e o recobre. Poder-se-ia dizer que, no momento em que o escritor escreve, o que ele conta, o que ele produz no próprio ato de escrever não é outra coisa senão a loucura. Esse risco de que um sujeito ao escrever seja levado pela loucura ... é justamente a característica do ato de escrita. É quando encontramos o tema da subversão da escrita. Penso que se possa ligar o caráter intransitivo da escrita, de que fala Barthes, a esta função de transgressão.” (FOUCAULT, (5) 1994, p.982). ${ }^{3}$

\section{Entre a suspensão cética do juízo e a valorização da escrita literária}

É sobre a necessidade argumentativa de uma epoche, de uma suspensão cética dos juízos que estamos falando; da eliminação de toda e qualquer noção que poderíamos ter verdadeiramente sobre a loucura e da tentação de analisá-la, classificá-la ou ordená-la consoante um ponto de vista retrospectivo ou racional. Esta a questão que nos coloca a História da Loucura. Contudo, não basta renunciar ao empréstimo de linguagens racionais historicamente constituídas para se libertar e ser capaz de pensar então de um modo mais autêntico. A equação proposta não é tão simples

3 (FOUCAULT; Folie, littérature, société in Dits et écrits I p.982). 
assim. Pois perceba também o leitor agora que não é de um "sujeito anônimo e geral da história" que estamos tratando, e sim de nomes próprios dados pela arqueologia em História da Loucura àqueles seus heróis talentosos o suficiente para fazerem a linguagem da loucura falar, do privilégio conferido pela pena de Foucault a personagens que figuram espirituosamente como os grandes (senão universais) escritores de nossos tempos.

Por mais que tenha se oposto e se afastado dos meios racionais e positivistas que a nossa civilização criou para lidar com a loucura tratando-a terapeuticamente como doença mental, arqueologicamente Foucault está antes descrevendo um conjunto de discursos que silenciaram uma celebração cultural que ele tanto admirava. Mesmo que a referência negativa ao universo político sartriano desde sempre tenha obcecado Foucault - pois não se trataria mais de formular um novo avatar do grande pensamento de esquerda totalizante ou do intelectual como autoridade moral - foi encontrando ainda assim no heroísmo destas figuras literárias e no modo de linguagem enunciado em sua obras, relacionador de escrita e experiência trágica, que a arqueologia buscou o apoio à redação de seu projeto para a abertura de um rumo histórico alternativo, quer dizer, não humanista. Como se sabe, Foucault não tardará a nos advertir acerca da mudança do papel hegemônico do intelectual em nossa sociedade. $O$ intelectual universal de esquerda, representante de toda a sociedade e portador da verdade ao possuir uma visão global dos acontecimentos, será substituído pelo intelectual específico cuja função renunciará a modelar a vontade política dos outros limitando-se ao papel crítico de reinterrogar as evidências e os postulados de nossa cultura; desconstruindo assim nossas maneiras habituais de pensamento e dissipando nossas familiaridades ingenuamente admitidas.

Meta-historicamente falando, portanto, o compromisso de Foucault com uma liberdade não humanista e anti-antropológica que colocasse toda a estrutura de nosso pensamento em questão o insere outrossim num dilema acerca da mudança histórica. Pois conforme sua tese exposta em $A$ Arqueologia do Saber acerca das descontinuidades históricas, a mudança, embora não possa ser explicitada dialeticamente por contradições internas ao campo mesmo da história (pois enfim ele não é um filósofo da história tal qual Hegel, Marx ou Sartre), tampouco poderia ser computada à voluntarista e deliberada ação discursiva de determinados autores (porque afinal ele também não é um positivista como Augusto Comte). Pois em 1969 o "novo arquivista”, na expressão de Deleuze, anunciará que só vai se ocupar da 
multiplicidade de enunciados que não se referem a nenhuma unidade, a nenhum Cogito, a nenhum sujeito transcendental que o tornasse possível, muito menos a algum espírito do tempo (Zeitgeist) ou a um sujeito da enunciação ao qual eles se remeteriam. ${ }^{4}$

Contra toda reafirmação de uma identidade substancial, o primado do múltiplo e da dispersão. Porém, atribuir a nomes específicos a capacidade de enunciação de um outro modo de articulação da linguagem é coisa bastante diferente. Grosso modo, tudo se passa como se através das obras desses personagens a cultura ocidental formulasse a construção de uma nova maneira de pensar e desconstruísse, ao mesmo tempo, nossa forma familiar de interpretação; como se, no lugar da figura unificadora das representações do sujeito ocidental, tivéssemos de direito a figura plural e inventiva da própria palavra literária. Imanência do campo transcendental, poder-se-ia dizer. $\mathrm{Na}$ linguagem de ficção literária, numa experiência que não se deixa apreender em nenhum lugar fixo, encontraríamos antes a criação de uma outra realidade e não sua representação; um duplo que não remeteria mais a um real precedente e originário tal qual uma linguagem segunda, mas ao seu ser mesmo já desapossado do autor como o dono de sua verdade. Todavia, ao associar a literatura moderna a uma experiência trágica da linguagem manifestada por vicejantes formas de consciência crítica da loucura, Foucault acaba por amarrar a letra da sua história arqueológica ao se deparar inevitavelmente com o "heroísmo" ou a "genialidade" desses autores. Pois ao colocar-se a escrever essa história da loucura sob o mesmo horizonte que torna possíveis essas obras de literatura, ele retoma inevitavelmente e por sua própria conta a função do autor em seu discurso. Numa palavra: fora justamente deste heroísmo que ele retirou a legitimidade para o aspecto crítico de seu pensamento.

Ora, mas pode-se entrever que a autoria é, na verdade, um procedimento de controle do discurso ao introduzir uma noção, tão cara ao seu projeto, restritora de toda a liberdade da palavra literária ao inseri-la num modelo representativo de constrangimento que Foucault justamente tanto

\footnotetext{
${ }^{4}$ Contrariamente à nossa interpretação e consoante a postura do próprio Foucault em 1969, Deleuze afirmará o seguinte: "Foucault junta-se a Blanchot, que denuncia toda personologia lingüística e situa os lugares do sujeito na espessura de um murmúrio anônimo. É o murmúrio sem começo nem fim que Foucault pretende se estabelecer, no lugar que os enunciados lhe reservam. $E$ talvez sejam esses os enunciados mais comoventes de Foucault." (DELEUZE, O Novo Arquivista em Foucault p.19).
} 
ansiava por se libertar. Pois afinal, conceitos como os de autor e obra, nascidos consoante sua própria análise em fins de século XVIII, estão ligados a uma concepção humanista de arte. Ser autor, em outras palavras, implica um modo preconcebido de produção e recepção do discurso historicamente datados. Embora o interesse de Foucault pela literatura faça parte de seu programa anti-humanista que circunda todo seu projeto, devido à possibilidade encontrada nela (a literatura) de se pensar fora da ditadura do sujeito, expressões ou conceitos "tão repugnantes" como o de profundidade continuarão ainda por exercer papéis demasiado relevantes em seu projeto. Em suma, é preciso constatar que Foucault nesta fase inicial de sua carreira ainda não se distanciou da idéia de "comentário", inclusiva tanto da pesquisa do fundamento oculto dos saberes quanto da tentativa de reavivar a inteligibilidade perdida de um discurso tomado como legítimo em outra época. ${ }^{5}$ Por sua própria estrutura, o procedimento do comentário supõe um desnível entre os saberes autorizando uma espécie de discurso segundo a duplicar o discurso comentado. Com o intuito de fazer surgir alguma verdade implícita no dito explícito do discurso primeiro, o comentário procura sempre uma origem mais remota a ser reencontrada e um sentido oculto a ser decifrado. Essa origem (Ursprung) e esse sentido simultaneamente mais essencial e reduzido ao silêncio - atravessam a significação explícita dos discursos como um sentido "já-dito" e ao mesmo tempo "jamais-dito". Trata-se pois sempre do projeto de trazê-lo à luz ou de fazê-lo falar pela via de um discurso duplicado. Ora, se dessa feita dizemos que Foucault obedece ao procedimento do comentário, segue-se daí que tal apreensão arqueológica da escritura literária não deixou também de inscrevê-

\footnotetext{
${ }^{5} \mathrm{~A}$ experiência literária da escrita, em seu desdobramento, encontra-se oposta à estrutura suposta pelo exercício do comentário. Já que este dispositivo implica necessariamente a origem de um sentido inicial e puro, sempre presente ao longo de nossa história mas jamais dado. Acerca da oposição da escrita arqueológica com a linguagem empreendida pelo próprio discurso literário, seguem-se as palavras do literato Blanchot: "colocar em evidência práticas discursivas quase que puras, no sentido que ela não reenviam senão a elas mesmas, às regras de sua formação, a seu ponto de ligação, ainda que sem origem, à sua emergência, ainda que sem autor, a deciframentos que não revelariam nada de oculto. Testemunhas que nada confessam, porque não têm nada a dizer (de algo) senão o que foi dito. Escritos rebeldes a todo comentário (ah, o horror de Foucault ao comentário). Domínios autônomos, mas não realmente independentes, nem imutáveis, dados que se transformam sem cessar, como os átomos à sua vez singulares e múltiplos, se se quiser admitir que há multiplicidades que não se referem a nenhuma unidade." (Blanchot, Foucault tal como o imagino; p.84).
} 
lo, ao menos em História da Loucura, dentro de uma indesejada tradição de discurso. 6

Sabe-se que esta é uma questão presente em toda a sua obra e que Foucault não tardará a se descartar dessa função autoral que restringe a liberdade e a contingência de nosso discurso aproximando-se, cada vez mais, do anonimato desejado para suas análises. Não obstante, o abandono completo das noções de autor e obra, correlato da importância assumida pela literatura em seu pensamento no início dos anos 60, será feito apenas mais tarde a partir de A Arqueologia do Saber (1969). De qualquer forma, já podemos avançar uma hipótese mais geral acerca do pensamento de Foucault no início dos anos 60 . Se nesse primeiro momento de sua trajetória filosófica, ele está acreditando na escritura literária, é porque ele acredita em sua exterioridade: nela está em jogo uma relação entre linguagem e loucura que lhe legitima a exercer um papel de contestação intelectual da sociedade moderna. ${ }^{7}$

\footnotetext{
6 Uma das características do discurso de Foucault será a proibição do uso desses processos tradicionais de escrita que são a interpretação e o comentário: dois processos que definem o que se chama de "discurso feito de referências". Eles supõem sempre dois níveis de estatutos opostos: um primeiro operando como referente - mormente uma essência, uma verdade ou fundamento que se detêm estáveis - e no pólo oposto os referidos (os objetos sobre os quais versam os discursos podendo variar indefinidamente).

${ }^{7}$ Sobre as razões fornecidas pelo próprio Foucault acerca do ocaso representado pela literatura como um antigo leitmotiv de seu pensamento e a inevitável mudança do papel do intelectual e de sua escrita na sociedade, observe-se 0 seguinte comentário: "Na minha opinião, 0 ato de escrever - um ato posto fora do sistema socioeconômico, tal como a circulação, a formação dos valores - funcionava até aqui, por sua própria existência, como uma força de contestação no que concerne à sociedade. [...] Portanto, o problema é o seguinte: acima de tudo, se os intelectuais franceses de hoje se encontram em uma situação absolutamente difícil e se são coagidos a experimentar uma espécie de vertigem, quando não de desespero, é porque, desde a revolução cultural chinesa, e, em particular, desde que os movimentos revolucionários se desenvolveram não apenas na Europa, mas no mundo inteiro, eles foram levados a formular esta série de questões: será que a função subversiva de escrita subsiste ainda? A época em que só 0 ato de escrever, de fazer existir a literatura por sua própria escrita bastava para expressar uma contestação, no que diz respeito à sociedade moderna, já não estaria acabada? [...] Agora que a burguesia, a sociedade capitalista desapossaram totalmente a escrita dessas ações, não estaria 0 fato de escrever apenas reforçando o sistema repressivo da burguesia? Não seria preciso cessar de escrever? [...] Alguns dos meus amigos mais próximos e mais jovens renunciaram definitivamente a escrever [...] Em face dessa renúncia em benefício da atividade política, não apenas fico admirado, como sou tomado por uma vertigem. Afinal, agora que não sou mais jovem, contento-me em continuar esta atividade que, talvez, perdeu algo desse censo crítico que eu quis lhe dar." (Foucault, Folie, littérature, société in Dits et écrits I p.982-983). Percebe-se pelo exposto acima que 0 aspecto crítico de contestação da escrita de Foucault no início do anos 60 perdera algo de subversivo em relação a um poder que nessa época era visto ainda como repressivo, mas que agora passará a exercer o papel de resistência em relação a um poder produtor de repressão.
} 
Se neste momento inicial de sua carreira Foucault está, portanto, contrapondo a história horizontal e temporal à história vertical e intemporal - Apolo a Dionísio - valorando um dos termos, é porque não alcançou ainda a sua tão pretendida anônima e transparente forma de escrita. Conforme sua escrupulosa proposta de descrição dos saberes de modo mais isento possível, não se poderia emitir juízo de valor qualquer acerca da história. Ocorre, porém, que o arqueólogo se desembarace de sua neutralidade e formule juízos críticos acerca da antropologia. Há de convirmos pois que existe um grande hiato entre a explicação nominalista de como práticas e discursos se tornaram historicamente possíveis e a afirmação ou negação da validade de tais discursos. Deste modo, a afirmação da descontinuidade em História da Loucura, por intermédio da letra desses personagens, pode ser lida como postulando uma liberdade de escrita mediante a qual podemos esclarecer os demais períodos, historicamente datados, como falsificadores de nossa mais original e autêntica estrutura trágica. Pois se o que se persegue é o anonimato, a escrita não poderia ser mais a tentativa de expressão de seu ser verdadeiro. $^{8}$

Em a História da Loucura não haverá ontologia possível de nossa linguagem sem a pressuposição de um impensado de nossa cultura recuperado por específicos autores. Em outras palavras, o modernismo literário representado por tais arautos positivos de uma linguagem mais originária da loucura personificou a crise cética de Michel Foucault. Pois afinal, acerca deles a arqueologia não suspende seu juízo (epoche), assim como o fez perante os demais saberes racionais; pelo contrário, neles ela encontra - e por isso mesmo cessa justamente aí a sua sképsis - um modo totalmente centrífugo e diferente de enunciação da linguagem que esta própria "nova maneira de escrever a história", em seu teor centrípeto, não

\footnotetext{
8 Vê-se pelo exposto que a arqueologia ainda não formulou uma nova definição do intelectual que abandona suas costumeiras pretensões de universalidade em prol de um papel específico: "Penso que os intelectuais - se é que esta categoria existe ou se é que deve existir ainda, o que não é certo, o que talvez não seja desejável - renunciam às suas velhas funções proféticas. E por isto, não penso apenas na sua pretensão a dizer o que se vai passar, mas na função do legislador à qual eles aspiraram durante tanto tempo. [...] O sábio grego, o profeta judeu e o legislador romano continuam a ser modelos que assediam aqueles que, nos nossos dias, fazem profissão de falar e escrever. Sonho com 0 intelectual destruidor das evidências e das universalidades, aquele que assinala nas inércias e coerções do presente os pontos de fraqueza, as aberturas, as linhas de força, aquele que, sem cessar, se desloca, que não sabe ao certo onde estará ou 0 que pensará amanhã, porque está por demais atento ao presente." (FOUCAULT, Le Nouvel Observateur, n. 644).
} 
fora contudo capaz de escrever. Ao invés de prosseguir indefinidamente com sua postura cética e interrogativa, Foucault, que desde então já pretendia seguir o rumo ditado por Samuel Becket, acabou por encontrar justamente uma ética intelectual para sua escrita que ainda soçobrava na autenticidade autoral conferindo assim um telos ao seu programa intelectual. Ou seja, a linguagem arqueológica termina por não possuir nem o mesmo mérito, nem a mesma estrutura de linguagem de seus heróis, pois afinal ela não alcança inteiramente a mesma pretensão de anonimato que caracteriza a escritura moderna. Parafraseando o dizer de Foucault em sua defesa de doutorado: para fazer falar esta loucura seria necessário ter o mesmo talento (ou a mesma linguagem) desses poetas.

Esta primeira forma de análise arqueológica levada a cabo pelo autor não é apenas e senão a interpretação do processo histórico de racionalização da loucura em seu "devir horizontal" sob a ótica constante de seu afrontamento vertical com uma suposta estrutura trágica e hierática; do confronto entre "as dialéticas da história com as estruturas imóveis do trágico.” (Foucault, (1) 2002, p.190). Pois essa experiência literária tão valorizada por Foucault exige que nos defrontemos verticalmente com os perigos da loucura. Em suas próprias palavras, a arqueologia é antes o estudo de

"Uma região, sem dúvida, onde se trataria mais dos limites do que da identidade de uma cultura. Poder-se-ia fazer uma história dos limites - desses gestos obscuros, necessariamente esquecidos logo que concluídos, pelos quais uma cultura rejeita alguma coisa que será para ela o Exterior; e, ao longo de sua história, esse vazio escavado, esse espaço branco pelo qual ela se isola a designa tanto quanto seus valores. Pois seus valores, ela os recebe e os mantém na continuidade da história; mas nessa região de que queremos falar, ela exerce suas escolhas essenciais, ela faz a divisão que lhe dá a face de sua positividade; ali se encontra a espessura originária na qual ela se forma. Interrogar uma cultura sobre suas experiênciaslimite é questioná-la, nos confins da história, sobre um dilaceramento que é como o nascimento mesmo de sua história. Então, encontram-se confrontados, em uma tensão sempre prestes a desenlaçar-se, a continuidade temporal de uma análise dialética e o surgimento, às portas do tempo, de uma estrutura trágica." (Foucault, (4) 2002, p.189). 
A história trágica é a história arqueológica através da qual se recorda as escolhas essenciais desde as quais uma cultura se define menos como afirmação de sua identidade constituída e mais como a recusa daquilo que doravante não mais é ela; por intermédio dessas "experiências-limite" além das quais somente os conteúdos positivos lograrão manter-se estáveis. O tempo histórico que imporá o silêncio horizontal através do qual a psiquiatria logrará constituir-se como "monólogo da razão sobre a loucura", confinando-a em doença mental em nossos dias, não é pois uma supressão total de sua diferença, é antes ou apenas uma ocultação dela. A loucura, deste modo, além de mera figura histórica negativa e interpretada como ausência de obra pelos saberes racionais, é também uma experiência originária, positiva, confiscada e ocultada pela razão; sobre a qual a investigação arqueológica intenciona realizar a hermenêutica de suas "fundações secretas", de sua verdade mais imemorial, pois sem nenhuma recordação amparada na linguagem de razão. Nessa essência da loucura, identificada na "experiência trágica”, encontra-se o critério de julgamento e avaliação das formas de loucura assumidas historicamente pela razão. Daí a inexistência concreta de nominalismo no que tange ao leitmotiv da prática arqueológica de Michel Foucault em História da Loucura.

Partindo dessas experiências extremas da linguagem literária, e não de verdades científicas terminais, pode-se operar portanto uma história da loucura não mais considerando seu devir horizontal como um progresso de racionalidade, e sim reinterpretando numa dimensão vertical todas as suas formas históricas ao relacioná-las com o retorno na modernidade dessa experiência trágica original. Essa história das formas negativas assumidas pela loucura realiza uma "recorrência às avessas" - isto é, a um passado mais que arcaico acerca do presente - ao creditar positivamente a este déficit da razão instrumental a referência positiva que possibilita ao arqueólogo julgar a produção teórica sobre a loucura. É sobre o direito de Foucault reivindicar para dentro de nossa cultura uma palavra que se situe no exterior dos limites impostos pela razão, de uma experiência da loucura localizada fora do escopo histórico, ou de uma linguagem que não escolha parcialmente pela razão versus a loucura, que estamos indagando. 


\section{Literatura e retórica}

No instante atual desse retorno da origem da linguagem, toda a nossa forma recuada, moderna ou psiquiátrica, de pensar a loucura perde sua razão de ser, sua justificativa racional e horizontal em que esteve amparada. Foucault não está, portanto, apenas tentando reivindicar uma escrita diferente, um outro lugar pelo qual pudéssemos desfazer nossas certezas positivas do presente. É verdade que de fato ele também o está; muito embora seja preciso perceber que a maneira de reivindicá-la não obedece de direito ao mesmo espaço conceitual em que a arqueologia localiza essa escrita. Pois ainda que seu pensamento incida sobre o presente e nasça nele enraizado, o espírito de suas démarches recusa-se a permanecer adstrito a nossa época desejando operar um outro sentido, uma outra interpretação histórica de nossa atualidade desabonadora de seus prejuízos humanistas e representativos. O deslizamento de sua pena por verdades já constituídas obedece ao intuito de abalar tudo o que nos seja apresentado como pronto e necessário. Retomar em seu projeto a linguagem da razão corresponderia a transigir com a anulação da loucura ao mutismo, contemporizando com a ordem da razão que torna a loucura cativa. Daí a necessidade de introduzir em seus estudos a justaposição de textos de ficção literária e de textos de análise, a fim de libertar nossa linguagem do triunfo de uma subjetividade antropológica a que tanto se opunha os escritos de Michel Foucault. Em verdade, melhor dizendo, essa justaposição encontra-se no mais das vezes misturando de maneira apressada elaborações de cunho analítico com conclusões retóricas de ordem prática.

A esse propósito, é relevante notar o viés pouco acadêmico da pena arqueológica ao assumir uma posição bastante definida e militante em relação ao seu objeto de estudo: a linguagem. Pois escrever, para Foucault, é um ato que obedece a uma estratégia bem definida, procurando produzir efeitos em seu interlocutor, conseguir uma vitória reintroduzindo a disputa retórica do discurso no interior mesmo do campo da análise. Um hábito é sempre uma disposição de expectativa em relação a alguma coisa que se repete. Ele só se realiza mediante uma situação presente que recupera do passado o critério a fim de emitir seus juízos acerca do futuro. Seu intuito, neste sentido, consiste em se valer da surpresa do leitor, de seu preconceito e resistência em encarar um texto antigo como um relato sério e objetivo dos 
fatos, para transformar esse mesmo preconceito em crítica demolidora de sua presunçosa e moderna suposição de cientificidade. E nisso ele pretende estar muito mais ao lado dos sofistas do que dos filósofos. ${ }^{9}$ Enquanto estes últimos situar-se-iam ainda numa estrutura representativa da verdade, desprezando a força persuasiva da palavra falada, a referência arqueológica a um uso retórico da palavra - via introdução de elementos extra-filosóficos em sua escrita - serve à finalidade de proporcionar uma desfamiliarização do seu leitor com o estatuto de uma linguagem da qual o arqueólogo ansiava por se libertar. Quando Michel Foucault toma então partido dos sofistas ou dos literatos, quer de um Cálicles e de um Trasímaco ou quer seja de um Blanchot, contra Platão - pois para a doutrina socrático-platônica o logos grego já possuía contrário - ele não o faz apenas a título provocativo; mas para reatar romanticamente com a autenticidade loquaz de nossas origens culturais.

Obviamente que não se trata de atribuir aqui ao filósofo e ao personagem Platão qualquer responsabilidade na exclusão com uma linguagem originária da loucura, imputação um pouco ridícula para o ponto de vista arqueológico, aliás. Trata-se antes de situá-lo apenas como o nome de um momento de ruptura de um conjunto coerente e da inauguração de um novo sistema de racionalidade, ou seja, o lugar de uma passagem entre dois tipos de historicidade. Uma primeira temporalidade de curta duração, em que a relação entre a "Razão-Desrazão" ainda não se estabelecia por contrariedade e exclusão, e uma segunda forma de temporalidade de longa duração, para falar em termos braudelianos, em que já nos familiarizamos com o conceito de desrazão aparecendo como a alteridade contrária e antitética da razão. Para aplacar uma "caótica e ameaçadora" linguagem comum à razão e à loucura, o discurso racional constituiu-se como uma vontade de verdade que assinala nossa cultura desde a postura anti-sofística de Sócrates.

\footnotetext{
${ }_{9}^{9}$ Acerca da necessidade histórica de se desembaraçar de uma postura filosófica, Foucault responderá exemplarmente o seguinte: "Ora, o senhor disse no começo que eu era filósofo. Isso me embaraça e gostaria de começar por esse ponto. Se essa palavra me faz dar uma parada, é porque eu não me considero filósofo. Não é falsa modéstia. Trata-se, antes, de uma das características fundamentais da cultura ocidental há 150 anos: a filosofia, hoje, não passa de um ofício de professor universitário. Desde Hegel, a filosofia é ensinada por universitários cuja função consiste menos em praticar a filosofia do que ensiná-la. O que outrora se referia ao mais elevado pensamento no Ocidente decaiu, hoje, para o nível da atividade considerada como a que tem menor valor no domínio da educação: este fato prova que a filosofia provavelmente já perdeu seu papel, sua função de autonomia." (FOUCAULT, Folie, littérature, société in Dits et écrits l; p.973).
} 
Assim, Sócrates teria sido o primeiro a designar um limite ao nosso pensamento legitimando seu aspecto sereno e reflexivo, privando-o pois do caráter de radicalidade imediato próprio às suas origens. Pois foi primeiramente através dos Diálogos de Platão que pudemos enxergar com olhar retrospectivo o Logos se reorganizando em torno da questão da verdade representativa, em torno de uma racionalidade fundada pela filosofia grega e na qual nós viemos a nos reconhecer posteriormente. ${ }^{10}$ Desta maneira, enquanto a filosofia platônica irá "humanizar-se" numa dialética tranqüilizadora tal como a de Sócrates - numa prática do logos que o consagrava exclusivamente à verdade e em que toda multiplicidade era já selecionada a partir da identidade de um modelo ideal - o discurso sofístico do arqueólogo, colocando-se retoricamente atrás da filosofia, pretende ser um jogo de linguagem, ao mesmo tempo de combate social e político, que procura nos reenviar para o lugar "onde nossa cultura operou algumas de suas escolhas originais". ${ }^{11}$

Daí o inusitado recurso de Foucault, quando se refere à literatura, a noções que parecem remontar a um fundo metafísico de história continuista, como as de anúncio, prefiguração ou antecipação. São ilustrativas a respeito dessa retorização do espaço filosófico as linhas dedicadas em História da Loucura à fala do Neveu de Rameau - de quem os modernos literatos serão

\footnotetext{
${ }_{10}$ Melindrosa questão em que enveredamos agora. Em toda a década de 60 , a única possível referência de Foucault a Platão, através da figura de Sócrates, encontra-se na citação do primeiro prefácio de História da Loucura realizada acima. Mais tarde, em A Ordem do Discurso, Foucault retornará a comentar essa relação de Platão com o discurso sofístico. "Eis que um século mais tarde a verdade mais alta já não residia no que era o discurso ou no que fazia, mas no que dizia: chegou um dia em que a verdade deslocou-se do ato ritualizado, eficaz e justo, de enunciação, para o próprio enunciado: para seu sentido, sua forma, seu objeto, sua relação com sua referência. Entre Hesíodo e Platão uma certa partilha estabeleceu-se, separando o discurso verdadeiro e o discurso falso; partilha nova, visto que doravante o discurso verdadeiro já não é o discurso precioso e desejável, visto que já não é o discurso ligado ao exercício do poder. O sofista é expulso." (FOUCAULT, A Ordem do Discurso, p.17-18).

11 Diferentemente da postura sofística de Foucault ao se referir à literatura, Sócrates nos Diálogos de Platão nunca toma a palavra com a finalidade de persuadir, de impor-se pela força, mas para buscar a verdade no movimento convergente de sua dialética harmonizadora dos opostos. É o que se pode observar também numa citação do Prefácio à transgressão de 1963 em que Foucault opõe escrita literária e linguagem filosófica. "É exatamente 0 inverso do movimento que tem sustentado, desde Sócrates sem dúvida, a sabedoria ocidental: a esta sabedoria a linguagem filosófica promete a unidade serena de uma subjetividade que triunfaria nela, estando por ela e através dela inteiramente constituída." (Prefácio à transgressão p.271 in Dits et Écrits I).
} 
os herdeiros ${ }^{12}$ - que já no século XVIII alegorizava abreviadamente, de modo mais profundo e análogo ao papel de Juliette e Justine do Marquês de Sade em As Palavras e as Coisas, o movimento que percorrerá a História. No paradoxo histórico de sua própria existência - de um antes que anuncia um depois que já estava nele contido virtualmente, e de um depois que não faz senão reescrever um antes que já o exprimia - o Sobrinho esboçava a grande linha interrompida da loucura que atravessa o livro de ponta a ponta: qual seja, o reaparecimento da loucura no domínio da linguagem.

"Qual é, assim, a significação dessa existência desatinada figurada pelo Neveu de Rameau, de um modo ainda mais secreto para seus contemporâneos porém decisivo para nosso olhar retrospectivo? É uma existência que mergulha bem longe no tempo [...] anunciando também as formas modernas do desatino (desrazão), as que são contemporâneas de Nerval, Nietzsche, e Antonin Artaud. Interrogar o Neveu de Rameau no paradoxo de sua existência tão evidente e, no entanto, despercebida no século XVIII, é colocar-se ligeiramente atrás em relação à crônica da evolução. Mas é, ao mesmo tempo, permitir-se perceber, em sua forma geral, as grandes estruturas do desatino (desrazão, grifo nosso) - as que dormitam na cultura ocidental, um pouco abaixo do tempo dos historiadores. E talvez o Neveu de Rameau nos mostrará rapidamente [...] o que existe de mais essencial nas modificações que renovaram a experiência do desatino (desrazão) na era clássica. É preciso interrogá-lo como paradigma abreviado da História. E dado que, durante a duração de um relâmpago, ele esboça a grande linha interrompida que vai da Nau dos Loucos às últimas palavras

12 "Ora, aquilo que Le Neveu de Rameau já indicava, e depois dele todo um modo literário, é 0 reaparecimento da loucura no domínio da linguagem, de uma linguagem onde lhe era permitido falar na primeira pessoa e enunciar, entre tantos propósitos inúteis e na gramática insensata de seus paradoxos, alguma coisa que tivesse uma relação essencial com a verdade. Essa relação começa agora a desembaraçar-se e a oferecer-se em todo o seu desenvolvimento discursivo. Aquilo que a loucura diz de si mesma é [...] uma verdade do homem, bastante arcaica e bem próxima, silenciosa e ameaçadora: uma verdade abaixo de toda verdade, a mais próxima do nascimento da subjetividade e a mais difundida entre as coisas." (FOUCAULT, História da Loucura, p.510 - H. F. 535). 
de Nietzsche e talvez até às vociferações de Artaud.” (FOUCAULT, (3) 1978, p.342). ${ }^{13}$

Todavia, é preciso dizer também que o lirismo retrospectivo dessas suas referências retóricas não recai sobre a alteridade de um futuro feliz, mas sim sobre a identidade de um presente senão feliz, ao menos não humanista. Embora exterior, a literatura moderna não é algo que se encontra arqueologicamente situada no futuro, pelo contrário, sua própria existência e permanência oculta ao longo dos séculos atesta que ela é uma realidade presente, mas que não se encontra plenamente acabada. Uma utopia lírica, portanto, transcenderia o real apreendendo-o como ponto futuro, já que de certa forma ela é sempre um projeto inacabado. Já o programa a que Foucault nos remete, ao seu turno, aponta para o presente, solo profundo de seus escritos arqueológicos, para uma certa idéia de literatura e de linguagem contra-representativa. A superação e a transgressão dos limites da idade moderna está contido no interior da própria cultura que a elabora. Não fora, portanto, apenas ou simplesmente da afirmação de uma irredutível diferença ao nosso modo de pensar ou a qualquer forma de universalidade possível que estivemos tratando!

\section{Conclusão}

Por mais que o diagnóstico fornecido dessa loucura originária, recuperada por tais poetas consoante a arqueologia, volta e meia a situe para fora (déhors) do escopo da história, o lugar a partir do qual Foucault escreve não está inserido senão para dentro desse espaço. Por mais que de fato toda a sua argumentação suponha a existência de uma loucura primeira e metafísica, ela visará resgatar antes a estrutura trágica de sua própria partilha, da recusa da desrazão e não de sua presença. Ele está a par, pois, de que não existe

\footnotetext{
${ }^{13}$ (Conferir ainda: "A história que teremos de escrever nesta última parte aloja-se no interior do espaço aberto pela fala do Neveau - mas, evidentemente, ela estará longe de abranger inteiramente esse espaço. última personagem em quem loucura e desatino (desrazão) se reúnem, o Neveau de Rameau é aquele no qual o momento da separação é prefigurado, igualmente." Foucault, História da Loucura; p.342 - H. F. p.364. "Nessas poucas páginas de Diderot, as relações entre razão e desatino (desrazão) assumem um novo rosto. $\mathrm{O}$ destino da loucura no mundo moderno está aí estranhamente prefigurado, e já quase iniciado. A partir daí, uma linha reta traça esse improvável caminho que vai logo até Antonin Artaud." História da Loucura p.344 H.F p.366).
} 
acesso a uma pura desrazão, a uma primitiva e pré-histórica essência da loucura, mas apenas à região de confronto entre a razão e desrazão neste ou naquele determinado contexto histórico. A experiência a ser reencontrada pelo arqueólogo além das positividades científicas não deve, pois, ser compreendida como a experiência da loucura por ela mesma. Daí porque seu projeto crítico das condições de possibilidade de uma psicologia pôde estar associado à suposição metafísica de uma loucura originária. $\mathrm{Na}$ falta de sua pureza primitiva, o viés vertical do arqueólogo só nos levará até a região fundamental em que razão e loucura estão em troca perpétua, confusamente implicadas existindo uma para outra em sua obscura raiz comum. Momento paradoxal em que loucura e razão estão ligadas pelo que já as separa e pelo qual pode se perceber o que as mantém, tal qual o logos grego, ainda em oposição. Seu movimento não implica então um salto qualitativo para fora da história, mas apenas para baixo dela em direção à região onde nossa cultura exerce suas "escolhas originais" e onde nossa história se constitui. Ipso facto, sua escrita infelizmente não obedece ao mesmo modo de intransitividade e auto-referência daquele pensamento vindo do exterior, de fora, excedente aos nossos limites históricos.

Não será, pois, mediante a ambição de alcançar uma heterotopia impossibilitadora de qualquer hermenêutica, de um outro espaço pelo qual sejamos capazes de descrever nosso topos, nesse local anônimo e exterior em que o próprio Foucault pretendia pensar nossa cultura e onde supostamente como leitores nos situaríamos, que poderemos entrever o lugar a partir do qual ele escrevia essa História da Loucura. Como um movimento de resistência e de contestação dos valores dados historicamente, a literatura abre um espaço novo em nossa cultura que despersonaliza todo aquele que tente se fixar na identidade da função subjetiva do autor. Porém, Foucault não foi capaz de seguir o mesmo caminho da literatura. À guisa de conclusão, poderíamos afirmar em jargão antropológico que a permanência de sua posição de escritor numa nostalgia de um mundo anterior à partilha histórica, e suas referências míticas a uma linguagem mais originária, não conseguiu ritualizar ou celebrar a mesma prática poética da literatura, recuperadora de uma linguagem não representativa, de um espaço de nãocartesianismo no pensamento moderno. 


\section{REFERÊNCIAS}

FOUCAULT, $\mathrm{M}$.

(1) A Arqueologia do Saber. Trad. L. F. Baeta Neves. Petrópolis : Vozes, 1972.

(2) A Ordem do Discurso. Trad. Laura Fraga de Almeida Sampaio. São Paulo : Loyola, 1999.

(3) História da Loucura. Trad. José T. Coelho Neto. São Paulo : Perspectiva, 1978.

(4) Ditos e Escritos I, Rio de Janeiro: Forense Universitária, 2002.

(5) Ditos e escritos II, Rio de Janeiro: Forense Universitária, 2002.

(6) Dits et écrits I, Paris : Gallimard, 1994.

BLANCHOT, M. "Michel Foucault tel que je l'imagine, Montpelier, Fata Morgana, 1986.

DELEUZE, G. Foucault, São Paulo : Brasiliense, 1988.

HEGEL, G. W. F.; Princípios da Filosofia do Direito, Guimaraens Editores : Lisboa, 1990.

MACHADO, R. Ciência e Saber - A trajetória da Arqueologia de Foucault. Rio de Janeiro : Graal, 1981.

Foucault, a filosofia e a literatura. Rio de Janeiro: Jorge Zahar Ed, 2001.

MACHERREY, P. Nas origens da História da Loucura - uma retificação e seus limites in Recordar Foucault. São Paulo : Brasiliense, 1985.

E-mail do autor: augustobach@yahoo.com.br

Recebido em: 11/2009

Aprovado em: 03/2010 